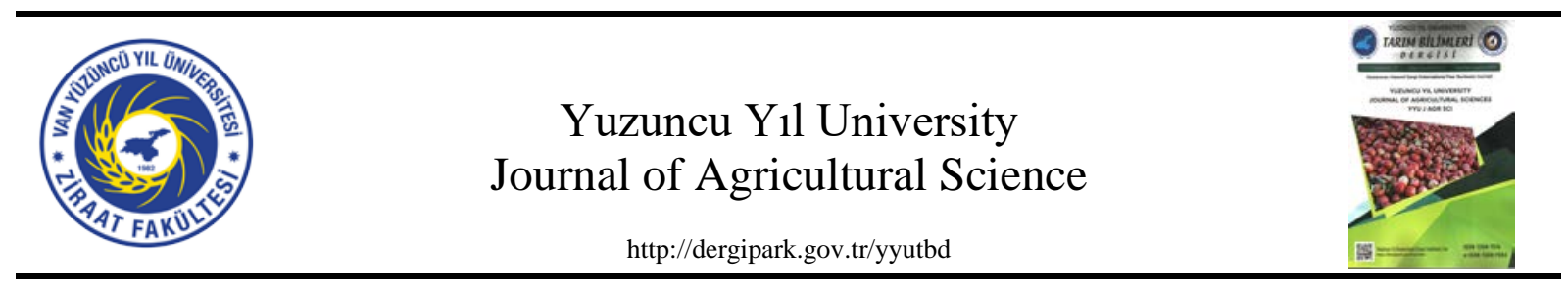

Araştırma Makalesi (Research Article)

Converting Iron Wastes to Nano Scale Zero Valent Iron: A Tool for Improving the Yield and Physiological Properties of Vegetables in Hydroponic Systems-Case Study, Broccoli in Floating System

\author{
Edris SHABANI ${ }^{* 1}$, Sahebali BOLANDNAZAR ${ }^{1}$, Hemattollah PIRDASHTI ${ }^{2}$ \\ ${ }^{1}$ University of Tabriz, Faculty of Agriculture, Department of Horticultural Science, Tabriz, Iran \\ ${ }^{2}$ Sari Agricultural Sciences and Natural Resources University, Faculty of Crop Science, Department of \\ Agronomy Science, Sari, Iran \\ **Corresponding author e-posta: edris.shabani@gmail.com
}

\section{Article Info}

Received: 20.04.2019

Accepted: 27.06.2019

Online Published 30.09.2019

DOI: 10.29133 /yyutbd.556395

\section{Keywords}

Growth,

Nano iron powders,

Nutrient solution,

$\mathrm{pH}$,

Photosynthesis pigments,

Yield.

\begin{abstract}
New achievements should be directed towards reducing iron deficiency in the plant and ultimately increasing the nutritional quality of agricultural products. An experiment was conducted to find the effects of various ratios of nano scales zero valent iron to iron chelate (NI/ Iron chelate) $(0: 100,25: 75$, 50:50, 75:25 and 100:0) at a concentration of $1.5 \mathrm{mg} \mathrm{L}^{-1}$ in different $\mathrm{pH}$ levels (5.5, 7.0 and 8.5) of nutrients solutions on yield, growth and photosynthesis pigments of broccoli plants in floating system. The experiment was designed as a factorial combination and treatments were arranged in a completely randomized design with three replicates. The results indicated that the growth of broccoli plants in terms of biomass and photosynthesis pigments were significantly affected by both different levels of NI/ Iron chelate and nutrient solution $\mathrm{pH}$. The highest amount of head fresh weight was observed in concomitant application of 50:50 ratio and $\mathrm{pH}=7.0$ nutrient solution, which was $32.53 \%$ more than the control treatment. The results of this experiment showed that the use of different ratios of NI/Iron chelate up to 50:50 levels improved the growth and yield of broccoli plants. As first report, the results of this experiment suggested that nano scale zero valent iron powders could increase the growth and yield of broccoli plants.
\end{abstract}

\title{
Demir Atıklarının Nano Ölçekte Sıfır Değerlikli Demire Dönüştürülmesi: Hidroponik Sistemlerde Sebzelerin Verim ve Fizyolojik Özelliklerinin Geliştirilmesi İçin Bir Araç, Yüzen Sistemde Brokoli Örneği
}

\section{Makale Bilgileri}

Geliș: 20.04.2019

Kabul: 27.06.2019

Online Yayınlanma 30.09.2019

DOI: 10.29133/yyutbd.556395

\section{Anahtar kelimeler}

Büyüme,

Nano demir tozu,

Besin çözeltisi,

$\mathrm{pH}$ değeri,

Fotosentez pigmentleri,

Verim.
Öz: Bitkilerdeki demir eksikliğinin azaltılması ve sonuçta tarım ürünlerinin besin kalitesinin arttırılması yönünde yeni kazanımlar elde edilmelidir. Çalıșma, faklı oranlarda nano ölçekte sıfır değerlikli demir ve demir şelatın (NI/Demir şelat) $(0: 100,25: 75,50: 50,75: 25$ ve 100: 0) 1,5 mg/L konsantrasyonunda ve farklı $\mathrm{pH}$ seviyelerindeki besin çözeltilerinde $(5.5,7.0$ ve 8.5$)$ yüzen sistemdeki brokoli bitkilerinin verimi, büyümesi ve fotosentez pigmentleri üzerine etkilerini görmek amacıyla yürütülmüştür. Deneme, tamamen tesadüfi faktöriyel deneme desenine göre üç tekerrürlü olarak tasarlanmıştır. Sonuçlar, brokoli bitkilerinin biyokütle ve fotosentez pigmentleri bakımından, farklı seviyelerde NI/Demir şelatı ve besin çözeltisi pH'sından önemli ölçüde etkilendiğini göstermiştir. En yükssek taze baş ağırlığı, kontrol uygulamasından \% 32.53 daha fazla olarak, 50:50 oranındaki ve $\mathrm{pH}=7.0$ besin çözeltisinin birlikte uygulanmasında gözlenmiştir. Bu araştırmanın sonuçları, farklı oranlarda 50: 50 
seviyelerine kadar NI/Demir şelatı kullanılmasının, brokoli bitkilerinin büyümesini ve verimini arttırdığını göstermiştir. İlk rapor olarak, bu deneme sonuçları, nano ölçekli sıfır değerli demir tozlarının brokoli bitkilerinin büyümesini ve verimini artırabileceğini göstermiştir.

\section{Introduction}

As the urban population is rising, the amount of municipal solid waste, one of the most important by-products of an urban lifestyle is growing even faster than the rate of urbanization (Hoornweg and Bhada-Tata, 2012). Global studies showed that, 4.3 billion urban residents generate 2.2 billion tonnes municipal solid waste per year until 2025 (Hoornweg and Bhada-Tata, 2012). In the United States alone, iron and steel recycled from scrap in 2015 was more than 52 million tons (Anonymus, 2019). Similar to increases in gross domestic product (GDP) and rates of urbanization, rates of municipal solid waste growth are fastest in the Middle East, China, other parts of East Asia, and parts of Eastern Europe (Hoornweg and Bhada-Tata, 2012). As a result, city administrators should manage solid waste in as holistic a manner as possible. Convert of iron wastes into nano scale zero valent iron (NZVI) is one of the best strategies for the proper management of them. There are various methods for the production of NZVI, which include chemical and physical methods. Chemical methods include liquid-phase reduction (Wang and Zhang, 1997), thermal decomposition (Zeng et al., 2017), micro emulsion (Li et al., 2003), chemical vapor condensation and physical methods include high-energy ball milling (Bonetti et al., 1999) and ultra sound shot peening (Guo et al., 2004). Nanotechnology can propose solution to enhancing the value of greenhouse products and environmental problems. With using of nano-powders and nano-particles, we can produce controlled or delayed releasing fertilizers (Sheykhbaglou et al., 2010). The high specific surface area of nanoparticles (NPs) increases their access to the plant and increases their solubility in water (Remya et al., 2010). NPs have high reactivity because of more density of reactive areas, more specific surface area, or increased reactivity of these areas on the particle surfaces. These traits facilitate the absorption of pesticides and fertilizers that produced in nano scale (Sheykhbaglou et al., 2010).

Nowadays, broccoli (Brassica oleraseae var. Italica) cultivation, especially in hydroponics, has been considered as a strong source of health food, containing various antioxidants such as vitamins and glucosinolates (Yuan et al., 2010). The importance of iron in its growth has been shown in previous reports (He et al., 2007; Pena-Olmos and Casierra-Posada, 2013). Iron is a micronutrient essential for normal plant growth and development. It plays an important role in the electron transport chain for both photosynthesis and respiration (Pena-Olmos and Casierra-Posada, 2013), chlorophyll and DNA synthesis, nitrogen fixation and hormone production (Vose, 1982). Iron is the fourth most abundant element in the earth's crust, but more than 30\% of the world's agricultural land has iron deficiency (Vose, 1982). Despite the fact that most of the iron in the plant is in the form of ferric $\left(\mathrm{Fe}^{+3}\right)$ in phosphoprotein bands, but in terms of metabolism the iron active form is ferrous $\left(\mathrm{Fe}^{+2}\right)$ (Vose, 1982). The solubility and availability of iron to plants is strongly depended on the chemical properties of the growth medium (e.g., $\mathrm{pH}$ and EC) and plant mechanism for iron acquisition (Ghafariyan et al., 2013). Therefore, sufficient access to iron is necessary in the medium. Zero-valent iron, $\mathrm{Fe}^{0}$, in the form of powder, is cheap and easy to get (Cao et al., 1999). Previous studies showed that the practical application of zero-valent iron was only in treating ground water and discoloring of waste water (Appleton, 1996; Cao et al., 1999). No studies have ever reported on the effect of NZVI on vegetable growth and yield.

The water alkalinity used for irrigation of greenhouse products is a major concern, since it has an adverse effect on plant nutrition and growth (Carter et al., 2005). It has been shown that Feethylenediaminetetraacetic acid (Fe-EDTA) has toxic effects on cell division, chlorophyll synthesis, and the production of biomass of photosynthetic organisms (Dufkova, 1984). Although, the use of FeEDTA in agriculture has been inevitable until today due to the high concentrations of bicarbonate in water and soil, but modern science should seek to find a way to reduce Fe-EDTA consumption due to its harmful effects. 
Therefore, new achievements should be directed towards reducing Fe-EDTA consumption and iron deficiency in the plant and ultimately increasing the nutritional quality of agricultural products (Oviedo and Rodriguez, 2003). Despite numerous studies on the effect of NPs on plants, no studies have been reported on the effect of NZVI on vegetables. As first report, we investigated the effects of various ratio of NZVI (produced from solid waste) to iron chelate in different $\mathrm{pH}$ on yield and physiological properties of broccoli in floating.

\section{Material and Methods}

\subsection{Plant material and growth conditions}

The experiment was conducted in 2016 growing season in a $200 \mathrm{~m}^{2}$ polyethylene greenhouse. Plants were grown under natural light conditions. The greenhouse was maintained at daily temperatures between 12 and $24^{\circ} \mathrm{C}$, and day/night relative humidity was $55 / 80 \%$, respectively. Seeds of broccoli (Brassica oleraseae var. Italica) were cultivated in trays containing perlite and cocopeat (1:1), and their nutrition after germination was performed with a $1 / 4$ and $1 / 2$ Hoagland's modified solution in appearance of cotyledon leaves and four-leaf stages, respectively [g 100 $\mathrm{L}^{-1}$ : potassium nitrate $\left(\mathrm{KNO}_{3}\right)$ : 50, calcium nitrate $\left(\mathrm{Ca}\left(\mathrm{NO}_{3}\right)_{2} \cdot 4 \mathrm{H}_{2} \mathrm{O}\right): 40$, monopotassium phosphate $\left(\mathrm{KH}_{2} \mathrm{PO}_{4}\right): 8$, magnesium sulfate $\left(\mathrm{MgSO}_{4} \cdot 7 \mathrm{H}_{2} \mathrm{O}\right): 10$, boric acid $\left(\mathrm{H}_{3} \mathrm{BO}_{3}\right): 20$, manganese sulfate $\left(\mathrm{MnSO}_{4} \cdot 4 \mathrm{H}_{2} \mathrm{O}\right)$ : 17 , zinc sulfate $\left(\mathrm{ZnSO}_{4} .7 \mathrm{H}_{2} \mathrm{O}\right): 15$, copper sulfate $\left(\mathrm{CuSO}_{4} \cdot 7 \mathrm{H}_{2} \mathrm{O}\right): 4$ and molybdate acid $\left(\mathrm{H}_{2} \mathrm{MoO}_{4} . \mathrm{H}_{2} \mathrm{O}\right)$ : 0.01 . The micronutrient stock was diluted 1:100 and then used in this experiment.

\subsection{Exposure of broccoli plants to various ratio of NZVI to iron chelate in different pH}

Uniform seedling were selected and transferred to the floating system $(7 \mathrm{~kg}$ plastic pots connected to the air pump with the spaghetti tubes). In the next step, the effect of five ratios of NI/Iron chelate at a concentration of $1.5 \mathrm{mg} \mathrm{L}^{-1}$ in three levels of $\mathrm{pH}$ : 5.5, 7.0 and 8.5 was evaluated. Potassium bicarbonate and sulfuric acid were used to adjust the $\mathrm{pH}$ at high and low levels of $\mathrm{pH}$, respectively. In order to prevent a significant change in the $\mathrm{pH}$ of the nutrient solution, this factor was monitored daily by $\mathrm{pH}$ meter and the nutrient solution in the pots was replaced every week. NZVI were purchased from the US Research Nanomaterials company (US-Nano, USA). These nano iron powders made with iron waste by the high-energy ball milling method. The size of NZVI particles was estimated to be $35-45 \mathrm{~nm}$ in diameter, metal basis and spherical. Figure 1 shows X-ray diffraction (XRD), scanning electron microscopy (SEM), transmission electron microscopy (TEM) and size distribution graph of NZVI. Deionised water was used to prepare 0, 25, 50, 75 and $100 \mathrm{mg} \mathrm{L}^{-1} \mathrm{NZVI}$ solutions and for further solving the NZVI and Fe-EDTA (control) were dispersed using ultrasonicator $(100 \mathrm{~W}, 40 \mathrm{khz})$ for $30 \mathrm{~min}$. The nutrient solution of the control treatment only prepared with a Hoagland's modified solution, iron chelate and deionized water.
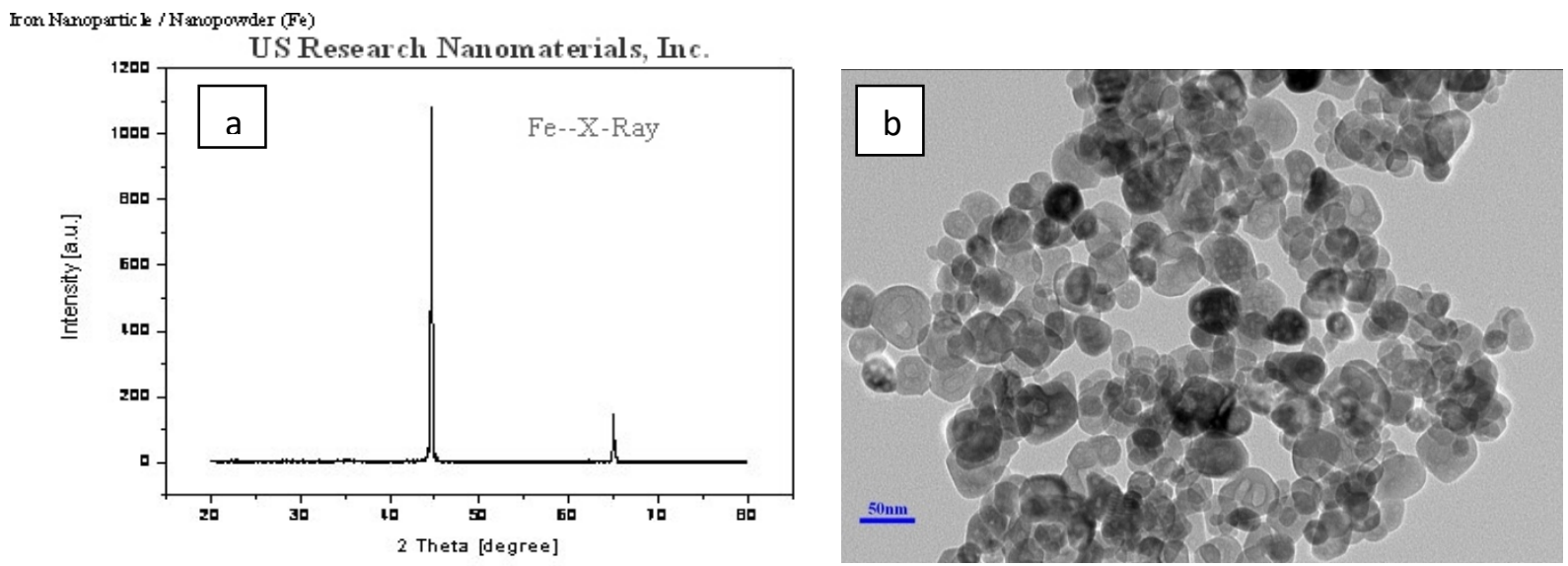


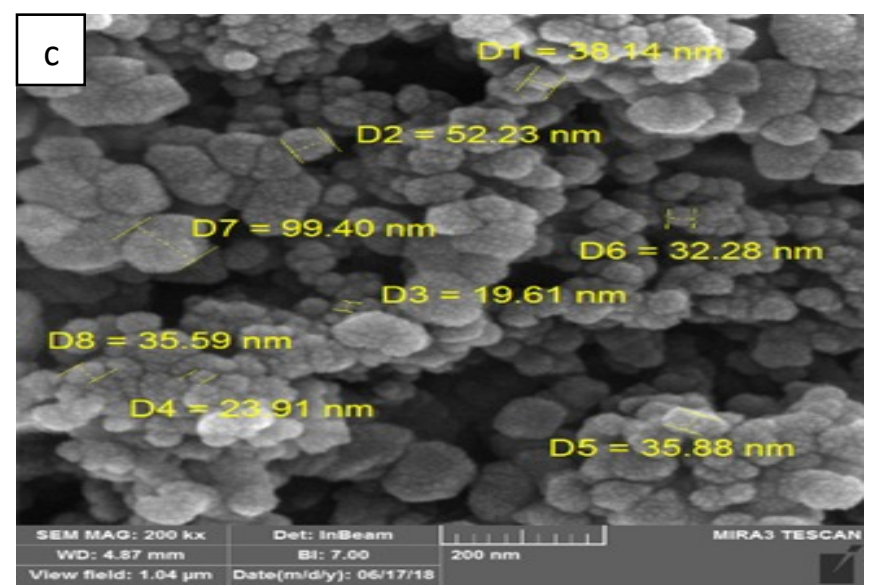

Figure 1. (a) X-ray diffraction (XRD), (b) transmission electron microscopy (TEM) and (c) scanning electron microscopy (SEM) images of spherical nano scale zero valent iron (NZVI).

\subsection{Growth measurement}

At the end of experiment, the broccoli plants were harvested and the fresh weights of head (FWH), leaf (FWL), shoot (FWS) and root (FWR) and number of leaves (NL) were measured. The leaf area meter (Li-Cor-Model: Li 1300, USA) was used to determine the leaf area (LA). Broccoli plants were oven dried at $70{ }^{\circ} \mathrm{C}$ for $48 \mathrm{~h}$ to determine the dry weights of leaf (DWL), shoot (DWS) and root (DWS) under different treatments.

\subsection{Measurement of photosynthesis indexes}

At fully expanded leaves a SPAD meter (SPAD-502, Minolta Camera Co., Osaka, Japan) was used to take SPAD value and photochemical efficiency (Fv/Fm) was recorded by Chlorophyll Fluorometer (Portable Chlorophyll Fluorometer PAM-2500, Walz Company, Germany). Determination of pigment amounts (chlorophyll a, chlorophyll b and carotenoid) using methanolic extract was performed by Carter and Knapp (2001) method. In all plants, fully expanded leaf was used for sampling. Extract absorption was read at 665.2, 652.4 and $470 \mathrm{~nm}$ wavelengths and calculated using the Lichtenthaler and Buschmann equation (2001).

\subsection{Statistical analysis}

All data were statistically analyzed by analysis of variance (ANOVA) using the SAS 9.1 software (SAS Inc., Cary NC). Duncan's multiple-range test was performed at $\mathrm{p}=0.05$ on each of the significant variables measured.

\section{Results}

\subsection{Effects of various ratio of NZVI to iron chelate}

The results indicated that the effects of NI/Iron chelate on FWH, LA, FWL, FWS, DWS, FWR, Chlorophyll a (Chl a), Chlorophyll b (Chl b), carotenoid (CAR), SPAD, $\mathrm{F}_{\mathrm{v}} / \mathrm{F}_{\mathrm{m}}$ in broccoli were highly significant (Tables 1 and 2). By increasing the concentration of NZVI up to $50 \mathrm{mg} \mathrm{L}^{-1}$, the growth and physiological characteristics of the broccoli were improved. With increasing NZVI concentration (75:25 and 100:0), decreasing trend was observed in growth and broccoli performance (Tables 1 and 2). By increasing the concentration of NZVI up to $50 \mathrm{mg} \mathrm{L}^{-1}$, FWH, photosynthetic indexes such as Chl a, b, and CAR, SPAD index increased by $76.23 \%, 76.77 \%, 44.33 \%, 47.10 \%$ and $15.65 \%$, respectively (Tables 1 and 2 ). 


\subsection{Effects of nutrient solution $\mathrm{pH}$}

In the present study, different levels of $\mathrm{pH}$ in the nutrient solution impressed the crop performance and photosynthesis parameter (Tables 1 and 2). Irrespective of NI/Iron chelate treatments, the highest amount of $\mathrm{FWH}$ was recorded at $\mathrm{pH}=7.0$ and the highest content of $\mathrm{LA}$, Chl $\mathrm{b}$, CAR and SPAD was observed at $\mathrm{pH}=5.5$. The $\mathrm{FWH}$ content in the neutral $\mathrm{pH}$ was $48.54 \%$ and 44.10\% higher than $\mathrm{pH}=5.5$ and $\mathrm{pH}=8.5$, respectively (Table 1 ).

Table 1. Mean effect of various ratio of nano scale zero-valent iron to iron chelate (NI/Iron chelate) and nutrient solution $\mathrm{pH}$ on fresh weight of head (FWH), number of leaves (NL), leaf area (LA), fresh weight of leaf (FWL), dry weight of leaf (DWL), fresh weight of shoot (FWS) and dry weight of shoot (DWS) of broccoli grown in floating system.

\begin{tabular}{|c|c|c|c|c|c|c|c|}
\hline Treatment & $\begin{array}{l}\text { FWH } \\
\left(\text { g plant }^{-1}\right)\end{array}$ & $\mathrm{NL}$ & $\begin{array}{c}\text { LA } \\
\left(\mathrm{cm}^{2} \text { plant }^{-1}\right)\end{array}$ & $\begin{array}{c}\text { FWL } \\
\left(\text { g plant }^{-1}\right)\end{array}$ & $\begin{array}{c}\text { DWL } \\
\left(\text { g plant }^{-1}\right)\end{array}$ & $\begin{array}{c}\text { FWS } \\
\text { (g plant }^{-1} \text { ) }\end{array}$ & $\begin{array}{c}\text { DWS } \\
\left.\text { (g plant }^{-1}\right)\end{array}$ \\
\hline \multicolumn{8}{|l|}{ NI/Iron chelate } \\
\hline $0: 100$ & $56.48^{b}$ & $16.66^{\mathrm{a}}$ & $1314^{b}$ & 233.65 bc & $105.07^{a b c}$ & $62.17^{\text {bc }}$ & $5.20^{a b}$ \\
\hline $25: 75$ & $93.94^{\mathrm{a}}$ & $17.66^{\mathrm{a}}$ & 1399 ab & $273.32 \mathrm{ab}$ & $119.32^{\mathrm{ab}}$ & $94.50^{a b}$ & $8.70^{\mathrm{a}}$ \\
\hline $50: 50$ & $99.54^{\mathrm{a}}$ & $18.16^{\mathrm{a}}$ & $1751^{\mathrm{a}}$ & $349.98^{a}$ & $140.54^{\mathrm{a}}$ & $120.17^{\text {a }}$ & $10.20^{\mathrm{a}}$ \\
\hline $75: 25$ & $43.40^{c}$ & $16.16^{\mathrm{a}}$ & $1052^{b}$ & 208.87 bc & $93.20^{c}$ & 58.50 bc & $4.81^{\mathrm{ab}}$ \\
\hline $100: 0$ & $29.14^{\mathrm{d}}$ & $16.33^{\mathrm{a}}$ & $535^{c}$ & $133.83^{c}$ & $73.53^{c}$ & $35.67^{c}$ & $2.38^{b}$ \\
\hline Significance & $* *$ & Ns & $* *$ & $* *$ & $* *$ & $* *$ & $*$ \\
\hline \multicolumn{8}{|c|}{ Nutrient solution $\mathrm{pH}$} \\
\hline 5.5 & $54.86^{c}$ & $17.10^{\mathrm{a}}$ & $1343^{a}$ & $238.49^{\text {a }}$ & $104.50^{\mathrm{a}}$ & $72.00^{a}$ & $6.12^{\mathrm{a}}$ \\
\hline 7.0 & $81.49^{a}$ & $17.40^{\mathrm{a}}$ & $1278^{a b}$ & $245.84^{\mathrm{a}}$ & $108.82^{\text {a }}$ & $81.40^{\mathrm{a}}$ & $6.96^{\mathrm{a}}$ \\
\hline 8.5 & $56.55^{b}$ & $16.50^{\mathrm{a}}$ & $1010^{b}$ & $235.46^{\mathrm{a}}$ & $105.67^{\mathrm{a}}$ & $69.20^{\mathrm{a}}$ & $5.70^{a}$ \\
\hline Significance & $* *$ & Ns & $*$ & Ns & Ns & Ns & Ns \\
\hline
\end{tabular}

$*$ and $* *$ significant differences between means at 0.05 and 0.01 level of probability, respectively; Ns, non-significant. Within each column in NI/Iron chelate or Nutrient solution $\mathrm{pH}$ treatments, means followed by the same letters are not significantly different at $5 \%$.

Table 2. Mean effect of various ratio of nano scale zero-valent iron to iron chelate (NI/Iron chelate) and nutrient solution $\mathrm{pH}$ on fresh weight of root (FWR), dry weight of root (DWR), chlorophyll a (Chl a), chlorophyll b (Chl b) and carotenoid (CAR), SPAD and $\mathrm{F}_{\mathrm{v}} / \mathrm{F}_{\mathrm{m}}$ index of broccoli grown in floating system.

\begin{tabular}{|c|c|c|c|c|c|c|c|}
\hline Treatment & $\begin{array}{c}\text { FWR } \\
\left.\text { (g plant }^{-1}\right)\end{array}$ & $\begin{array}{c}\text { DWR } \\
\left.\text { (g plant }{ }^{-1}\right)\end{array}$ & $\begin{array}{c}\text { Chl a } \\
\left(\mathrm{mg} \mathrm{g}^{-1}\right)\end{array}$ & $\begin{array}{c}\text { Chl b } \\
\left(\mathrm{mg} \mathrm{g}^{-1}\right)\end{array}$ & $\begin{array}{c}\text { Car } \\
\left(\mathrm{mg} \mathrm{g}^{-1}\right)\end{array}$ & SPAD & $\mathrm{F}_{\mathrm{v}} / \mathrm{F}_{\mathrm{m}}$ \\
\hline \multicolumn{8}{|l|}{ NI/Iron chelate } \\
\hline 0:100 & $46.63^{a b c}$ & $2.65^{\mathrm{a}}$ & $1.55^{\mathrm{bc}}$ & $1.06^{\mathrm{b}}$ & $1.38^{b}$ & 52.96 bc & $0.74^{\mathrm{a}}$ \\
\hline $25: 75$ & $60.12^{a b}$ & $3.78^{a}$ & $2.01^{\mathrm{b}}$ & $1.07^{\mathrm{b}}$ & $1.40^{\mathrm{b}}$ & $57.28^{a b}$ & $0.75^{a}$ \\
\hline $50: 50$ & $71.52^{\mathrm{a}}$ & $4.26^{\mathrm{a}}$ & $2.74^{\mathrm{a}}$ & $1.53^{\mathrm{a}}$ & $2.03^{\mathrm{a}}$ & $61.25^{\mathrm{a}}$ & $0.76^{a}$ \\
\hline $75: 25$ & $41.43^{\mathrm{bc}}$ & $2.51^{\mathrm{a}}$ & $1.03^{c d}$ & 0.65 bc & $0.96^{\text {bc }}$ & $47.91^{c}$ & $0.72^{\mathrm{a}}$ \\
\hline 100:0 & $28.00^{c}$ & $2.10^{a}$ & $0.65^{d}$ & $0.48^{c}$ & $0.68^{c}$ & $35.03^{d}$ & $0.59^{b}$ \\
\hline Significance & $* *$ & Ns & $* *$ & $* *$ & $* *$ & $* *$ & $* *$ \\
\hline \multicolumn{8}{|l|}{ Nutrient solution $\mathrm{pH}$} \\
\hline 5.5 & $50.93^{a}$ & $2.58^{a}$ & $1.92^{\mathrm{a}}$ & $1.21^{\mathrm{a}}$ & $1.64^{\mathrm{a}}$ & $60.50^{\mathrm{a}}$ & $0.75^{a}$ \\
\hline 7.0 & $48.42^{a}$ & $2.89^{\mathrm{a}}$ & $1.39^{\mathrm{a}}$ & $0.92^{a b}$ & $1.10^{\mathrm{b}}$ & $48.68^{b}$ & $0.69^{\mathrm{a}}$ \\
\hline 8.5 & $49.27^{a}$ & $3.72^{a}$ & $1.46^{\mathrm{a}}$ & $0.75^{b}$ & $1.13^{\mathrm{b}}$ & $43.49^{b}$ & $0.72^{a}$ \\
\hline Significance & Ns & Ns & Ns & $*$ & $* *$ & $* *$ & Ns \\
\hline
\end{tabular}

$*$ and ${ }^{* *}$ significant differences between means at 0.05 and 0.01 level of probability, respectively; Ns, non-significant. Within each column in $\mathrm{NI} /$ Iron chelate or Nutrient solution $\mathrm{pH}$ treatments, means followed by the same letters are not significantly different at $5 \%$.

\subsection{Combined effects of various ratio of NZVI to iron chelate and nutrient solution pH}

The concomitant use of NI/Iron chelate and nutrient solution $\mathrm{pH}$ significantly impresses growth and physiological parameter such as FWH (Figure 2), LA, FWL, DWL, FWS, FWR, Chl a, Chl b, CAR, SPAD and $F_{v} / F_{m}$ (Tables 3 and 4). The highest amounts of growth and yield were recorded at treatments of 50:50 $\times 7.0$ (Table 3, 4 and Figure 2). The highest amount of photosynthetic pigments, growth and broccoli yield were observed at 50:50 ratio and $\mathrm{pH}=7.0$. The results of this 
experiment showed that the simultaneous use of $\mathrm{NI} / \mathrm{Iron}$ chelate and nutrient solution $\mathrm{pH}$ increased FWH by 32.53\% compared to control treatment (Figure 2). Low concentrations of NZVI in comparison with control treatment in the basic and acidic conditions have shown more ability to improve growth characteristics such as LA, FWL, DWL and FWS (Table 3). At high levels of bicarbonate $(\mathrm{pH}=8.5)$, with the addition of $\mathrm{NI} / \mathrm{Iron}$ chelate up to $50 \mathrm{mg} \mathrm{L}^{-1}$, the SPAD, and $\mathrm{Fv} / \mathrm{Fm}$ index, Photosynthetic pigments and root growth showed a significant increase compared to the control treatment (Table 4).

Table 3. Interaction of various ratio of nano scale zero-valent iron to iron chelate (NI/Iron chelate) and nutrient solution $\mathrm{pH}$ on fresh weight of head (FWH), number of leaves (NL), leaf area (LA), fresh weight of leaf (FWL), dry weight of leaf (DWL), fresh weight of shoot (FWS) and dry weight of shoot (DWS) of broccoli grown in floating system.

\begin{tabular}{|c|c|c|c|c|c|c|}
\hline Treatment & NL & $\begin{array}{c}\text { LA } \\
\left(\mathrm{cm}^{2} \text { plant }^{-1}\right)\end{array}$ & $\begin{array}{c}\text { FWL } \\
\left.\text { (g plant }^{-1}\right)\end{array}$ & $\begin{array}{c}\text { DWL } \\
\left.\text { (g plant }^{-1}\right)\end{array}$ & $\begin{array}{c}\text { FWS } \\
\left.\text { (g plant }^{-1}\right)\end{array}$ & $\begin{array}{c}\text { DWS } \\
\text { (g plant }^{-1} \text { ) }\end{array}$ \\
\hline \multicolumn{7}{|l|}{ NI/ Iron chelate $\times p H$} \\
\hline $0: 100 \times 5.5$ & $15.00 \mathrm{ab}$ & 1372 bc & 171.40 bcd & 78.60 bc & $41.00 \mathrm{bc}$ & $3.05^{a b}$ \\
\hline $0: 100 \times 7.0$ & $18.00^{a b}$ & $1609^{b}$ & 338.60 abc & $145.65^{a b}$ & $102.00^{a b c}$ & $9.85^{\mathrm{ab}}$ \\
\hline $0: 100 \times 8.5$ & $17.00 \mathrm{ab}$ & 961 bcd & 190.95 bcd & $90.95 \mathrm{abc}$ & $43.50^{\text {bc }}$ & $2.70^{\mathrm{ab}}$ \\
\hline $25: 75 \times 5.5$ & $17.00 \mathrm{ab}$ & 1414 bc & 252.80 abcd & $102.35 \mathrm{abc}$ & $95.00 \mathrm{abc}$ & $6.20^{a b}$ \\
\hline $25: 75 \times 7.0$ & $17.00^{a b}$ & 1119 bc & $192.10^{\text {bcd }}$ & $96.60^{\mathrm{abc}}$ & 71.00 bc & $8.00^{a b}$ \\
\hline $25: 75 \times 8.5$ & $19.00 \mathrm{ab}$ & $1586^{b}$ & $375.05^{a b}$ & $159.00^{\text {a }}$ & 117.50 ab & $11.90^{\mathrm{a}}$ \\
\hline $50: 50 \times 5.5$ & $18.00^{\mathrm{ab}}$ & $1550^{b}$ & $293.85^{\text {abcd }}$ & $123.47^{a b c}$ & 93.00 abc & $9.40^{\mathrm{ab}}$ \\
\hline $50: 50 \times 7.0$ & $19.50^{\text {a }}$ & $2286^{a}$ & $417.40^{a}$ & $153.70^{\mathrm{a}}$ & $160.00^{\mathrm{a}}$ & $12.30^{\mathrm{a}}$ \\
\hline $50: 50 \times 8.5$ & $17.00 \mathrm{ab}$ & $1415^{\mathrm{bc}}$ & 338.70 abc & $144.45^{\mathrm{ab}}$ & $107.50^{a b c}$ & $8.90^{a b}$ \\
\hline $75: 25 \times 5.5$ & $18.50^{a b}$ & 1444 bc & 303.60 abcd & $129.95 \mathrm{abc}$ & $89.00^{\mathrm{abc}}$ & $8.55^{\mathrm{ab}}$ \\
\hline $75: 25 \times 7.0$ & $15.50 \mathrm{ab}$ & 1008 bcd & 170.40 bcd & $78.90^{\text {bc }}$ & 49.50 bc & $3.45^{a b}$ \\
\hline $75: 25 \times 8.5$ & $14.50^{b}$ & $705^{\mathrm{cd}}$ & $152.60^{\mathrm{cd}}$ & $70.75^{c}$ & $37.00^{c}$ & $2.45^{\mathrm{ab}}$ \\
\hline $100: 0 \times 5.5$ & $17.00 \mathrm{ab}$ & 933 bcd & $170.80^{\mathrm{bcd}}$ & 88.15 abc & $42.00^{b c}$ & $3.40^{\mathrm{ab}}$ \\
\hline $100: 0 \times 7.0$ & $17.00^{a b}$ & $290^{d}$ & $110.70^{d}$ & $69.25^{c}$ & $24.50^{d}$ & $1.20^{\mathrm{b}}$ \\
\hline $100: 0 \times 8.5$ & $15.00 \mathrm{ab}$ & $382^{d}$ & $120.00^{d}$ & $63.20^{\mathrm{d}}$ & $40.50^{b c}$ & $2.55^{\mathrm{ab}}$ \\
\hline Significance & Ns & * & $*$ & $*$ & $*$ & Ns \\
\hline
\end{tabular}

*, significant differences between means at 0.05 level of probability; Ns, non-significant. Within each column in NI/Iron chelate or Nutrient solution $\mathrm{pH}$ treatments, means followed by the same letters are not significantly different at $5 \%$.

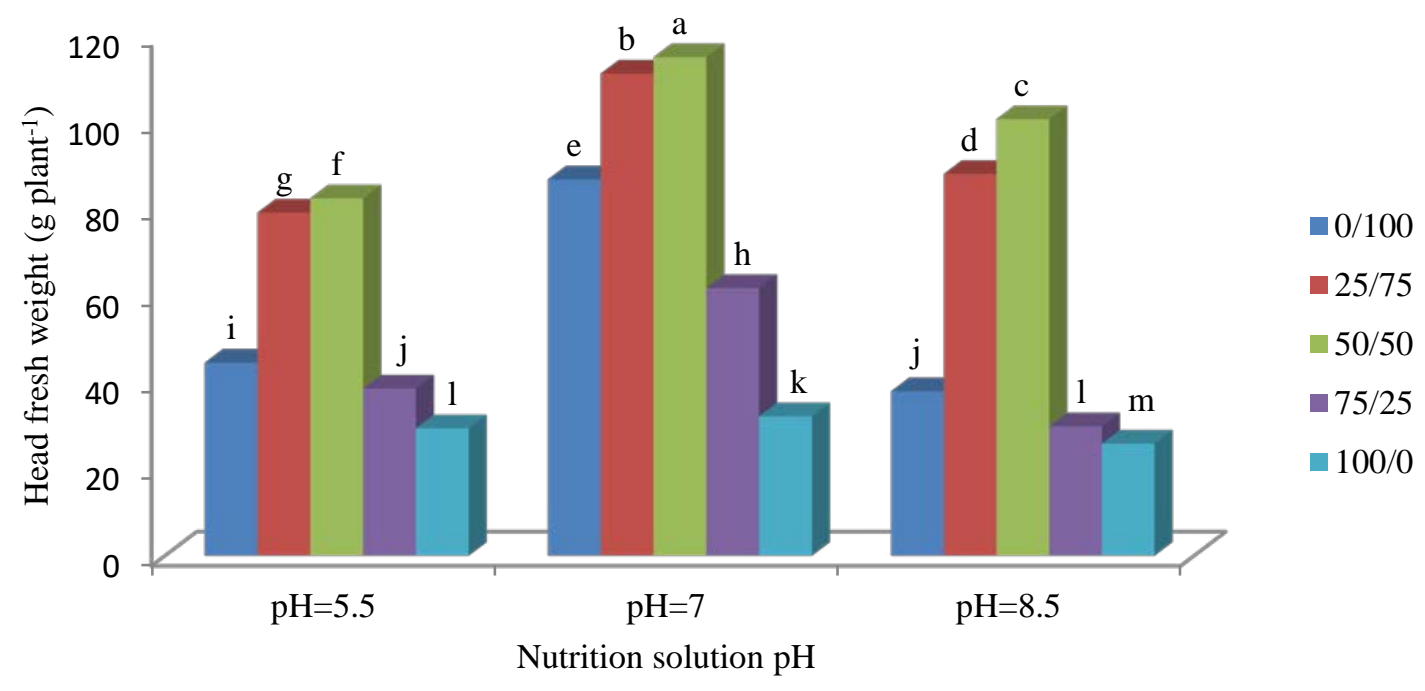

Figure 2. Interaction of various ratios of nano scale zero-valent iron to iron chelate and nutrient solution $\mathrm{pH}$ on head fresh weight of broccoli grown in floating system. Histograms with a differing letter are significantly different by Duncan’s multiple range test $(\mathrm{p}<0.01)$. 
Table 4. Interaction of various ratio of nano scale zero-valent iron to iron chelate and nutrient solution $\mathrm{pH}(\mathrm{NI} \times \mathrm{pH})$ on fresh weight of root (FWR), dry weight of root (DWR), chlorophyll a (Chl a), chlorophyll b (Chl b) and carotenoid (CAR), SPAD and $\mathrm{F}_{\mathrm{v}} / \mathrm{F}_{\mathrm{m}}$ index of broccoli grown in floating system.

\begin{tabular}{|c|c|c|c|c|c|c|c|}
\hline Treatment & $\begin{array}{c}\text { FWR } \\
\text { (g plant }^{-1} \text { ) }\end{array}$ & $\begin{array}{c}\text { DWR } \\
\left.\text { (g plant }^{-1}\right)\end{array}$ & $\begin{array}{c}\text { Chl a } \\
\left(\mathrm{mg} \mathrm{g}^{-1}\right)\end{array}$ & $\begin{array}{c}\text { Chl b } \\
\left(\mathrm{mg} \mathrm{g}^{-1}\right)\end{array}$ & $\begin{array}{c}\text { Car } \\
\left(\mathrm{mg} \mathrm{g}^{-1}\right)\end{array}$ & SPAD & $\mathrm{F}_{\mathrm{v}} / \mathrm{F}_{\mathrm{m}}$ \\
\hline \multicolumn{8}{|c|}{ NI/ Iron chelate $\times p H$} \\
\hline $0: 100 \times 5.5$ & $34.80^{b c}$ & $1.50^{b}$ & $2.02^{a b c}$ & $1.42^{a b}$ & $1.92^{a b}$ & $56.95^{\mathrm{abc}}$ & $0.75^{a}$ \\
\hline $0: 100 \times 7.0$ & $72.60^{a b}$ & $4.55^{\mathrm{ab}}$ & 1.52 bcde & 0.86 bcd & 1.28 bcdef & 52.85 bcd & $0.75^{a}$ \\
\hline $0: 100 \times 8.5$ & 32.50 bc & $1.90^{\mathrm{b}}$ & 1.11 bcde & $0.91 \mathrm{bcd}$ & $0.95^{\text {cdefg }}$ & $49.10^{\mathrm{bcd}}$ & $0.73^{a}$ \\
\hline $25: 75 \times 5.5$ & $45.05 \mathrm{abc}$ & $1.80^{\mathrm{b}}$ & $2.29 \mathrm{abc}$ & $1.19^{\mathrm{abc}}$ & 1.79 abcd & $60.45^{a b}$ & $0.76^{\mathrm{a}}$ \\
\hline $25: 75 \times 7.0$ & $45.70 \mathrm{abc}$ & $2.25^{b}$ & $1.64^{\mathrm{abcd}}$ & $1.10^{\mathrm{abc}}$ & $0.76^{\text {efg }}$ & $57.20^{\mathrm{abc}}$ & $0.72^{a}$ \\
\hline $25: 75 \times 8.5$ & $89.60^{\mathrm{a}}$ & $7.30^{a}$ & $2.07 \mathrm{abc}$ & 0.92 bcd & 1.65 abcde & 54.20 abcd & $0.77^{\mathrm{a}}$ \\
\hline $50: 50 \times 5.5$ & $74.95^{a b}$ & $3.95^{\mathrm{ab}}$ & $2.38 \mathrm{ab}$ & $1.56^{a b}$ & $1.94^{\mathrm{ab}}$ & $67.60^{\mathrm{a}}$ & $0.74^{\mathrm{a}}$ \\
\hline $50: 50 \times 7.0$ & $76.70^{\mathrm{ab}}$ & $4.55^{\mathrm{ab}}$ & $2.92^{\mathrm{a}}$ & $1.73^{\mathrm{a}}$ & $2.35^{\mathrm{a}}$ & $63.60^{\mathrm{ab}}$ & $0.78^{a}$ \\
\hline $50: 50 \times 8.5$ & $62.90 \mathrm{abc}$ & $4.30 \mathrm{ab}$ & $2.92^{\mathrm{a}}$ & $1.31^{\mathrm{ab}}$ & $1.81^{\mathrm{abc}}$ & 52.55 bcd & $0.75^{\mathrm{a}}$ \\
\hline $75: 25 \times 5.5$ & $66.50 \mathrm{abc}$ & $3.45^{a b}$ & 1.60 abcd & $1.08 \mathrm{abc}$ & 1.39 bcdef & $58.55^{a b c}$ & $0.75^{a}$ \\
\hline $75: 25 \times 7.0$ & $28.60^{\text {bc }}$ & $2.00^{b}$ & 0.49 de & $0.44^{\mathrm{cd}}$ & $0.61^{\mathrm{fg}}$ & $44.10^{\mathrm{cd}}$ & $0.75^{a}$ \\
\hline $75: 25 \times 8.5$ & $29.20^{\text {bc }}$ & $2.10^{b}$ & 1.01 cde & $0.45^{\mathrm{cd}}$ & $0.90^{\text {defg }}$ & $41.10^{\mathrm{d}}$ & $0.75^{a}$ \\
\hline $100: 0 \times 5.5$ & 33.35 bc & $2.20^{b}$ & 1.33 bcde & $0.82 \mathrm{bcd}$ & $1.20^{\text {bcdefg }}$ & $58.95^{\mathrm{ab}}$ & $0.75^{a}$ \\
\hline $100: 0 \times 7.0$ & $18.50^{\mathrm{c}}$ & $1.10^{b}$ & 0.41 de & $0.47^{\mathrm{cd}}$ & $0.49^{\mathrm{fg}}$ & $25.65^{\mathrm{e}}$ & $0.47^{b}$ \\
\hline $100: 0 \times 8.5$ & $32.15^{b c}$ & $3.00 \mathrm{ab}$ & $0.22^{\mathrm{e}}$ & $0.16^{d}$ & $0.37^{\mathrm{g}}$ & $20.50^{\mathrm{e}}$ & $0.55^{b}$ \\
\hline Significance & $*$ & Ns & $*$ & $*$ & $*$ & $*$ & $*$ \\
\hline
\end{tabular}

*, significant differences between means at 0.05 level of probability; Ns, non-significant. Within each column in NI/Iron chelate or Nutrient solution $\mathrm{pH}$ treatments, means followed by the same letters are not significantly different at $5 \%$.

\section{Discussion and Conclusion}

The results of this experiment showed that the head fresh weight in 50:50 treatments at all $\mathrm{pH}$ levels was greater than of control plants and the highest yield was recorded in $\mathrm{pH}=7.0$. Low and medium concentrations of NZVI at $\mathrm{pH}=5$ and 8.5 indicated no significant difference on LA in comparison with control treatment. Probably the reason for the decrease in LA at high concentrations of nano particles is the reduction of hydraulic conductivity in the primary roots; thereby, leading to reduced transpiration and leaf growth (Rico et al., 2011).

Our finding clearly demonstrated that vegetative and physiological characteristics in all levels of nutrient solution $\mathrm{pH}$ and the ratio of 50:50 NI/Iron chelate were higher than control treatment. The findings of Ghafariyan et al. (2013) in soybeans showed that super paramagnetic iron oxide NPs (SPIONs) due to higher concentrations of $\mathrm{Fe}^{2+}$ in the growth medium and the exudation of macromolecules such as protein and polysaccharide from the root surface cause better growth of root and shoot, and also increase chlorophyll content. NPs cover by these macromolecules and entrance into the fluids containing biomolecules (Rauch et al., 2013). Also, it is proven that these macromolecules could change NPs physicochemical properties and affect their uptakes and translocations into rhizosphere and xylem sap (Judy et al., 2012).

There are repugnant reports on the absorption of NPs and their impact on plant growth. For example, finding of Zhu et al. (2008) showed that $\mathrm{Fe}_{3} \mathrm{O}_{4}$ NPs can uptake by pumpkin (Cucurbita mixta) in aqueous medium, whereas, Wang et al. (2011) did not observe any uptake of $\mathrm{Fe}_{3} \mathrm{O}_{4}$ NPs by pumpkin plants. It is hypothesized that it is difficult for the larger size NPs to penetrate through the cell walls and transport across the plasma membranes. Also, the results of Ghafariyan et al. (2013) in soybeans showed that SPIONs penetrate into the root, traverse to the xylem, and translocate into the shoot. It is hypothesized that SPIONs diffuse from xylem's sap to aerial parts with symplastic transport and apoplastic flow. Transpiration and evaporation are responsible for accumulated of SPIONs in the margin of leaves. Our results showed that, assuming confirmation of these theories, we must state that the importance of NPs concentrations is similar its size. Because of that, the application of NZVI with an average of $40 \mathrm{~nm}$ at low and medium nano levels was favorable for broccoli growth and yield. It seems that NPs due to high specific surface area and high reactivity may enter plant roots through capillary forces, osmotic pressure, intercellular plasmodesmata and pores in cell walls, or via 
the highly regulated symplastic route and selective uptake and translocation (Nowack and Bucheli, 2007). Therefore, it can state that exudation of macromolecules, transpiration and evaporation and high reactivity of NPs are three important factor which responsible for uptake of these particles in plant tissues. Also, it has been shown that properties of NPs, such as size, composition, shape, and surface charge may affect the uptake and translocation inside plant (Jia et al., 2005; Zhu et al., 2009). This experiment showed that the concentration of NPs is another important factor in uptake of these particles.

There was no significant difference in the amount of photosynthetic pigments and SPAD index between control treatment and low and middle ratios of NI/Iron chelate (except 50:50 ratio and $\mathrm{pH}=7.0$ for Chl a, Chl b). Only in the ratios of 75:25 and 100:0 $\mathrm{mg} \mathrm{L}^{-1}$ decreased photosynthetic pigmentation and photosynthetic efficiency. This result suggests that root environment is acidified by protons for releasing of Fe ions from NZVI and then the iron ions are used inside the chloroplast stroma and tylakoid. Ghafariyan et al. (2013) demonstrated that SPIONs could prepare iron ions with redox reactions involved in the chloroplast. The biochemical reactions in chloroplast stroma, siderophore in the tylakoidal membranes, and photocatalytic reaction are proposed as factors for iron availability from SPIONs.

We notice deficiency symptoms lead to chlorosis spots covering the leaf surface in the plants for 75:25 and 100:0 treatments. It seems that NZVI accumulate on the root surface and occlude some water and ion channels (Ghafariyan et al., 2013) or leakage of cytoplasmic content and membrane disruption, clog the root openings and inhibit both hydraulic conductivity and nutrient uptake in roots (Rico et al., 2011). As a result, high concentrations of NZVI negatively affected plant development. Also, the emergence of broccoli heads even in a small form (amount) was observed at high NZVI concentrations. Findings of Tan et al. (2007) showed that rice plants indicate self-defense response, when exposed to multi walled carbon nanotubes, by killing a small population of cells that aggregates with the NPs and precipitates. This protected the remainder of the cells in culture. It seems that a mechanism similar to this phenomenon has been done to protect other broccoli cells at high concentrations of NZVI.

\subsection{Conclusion}

The results of this experiment showed that:

1- The use of different ratios of NI/Iron chelate up to 50:50 level increased head fresh weight, growth and physiological parameters of broccoli plants. It seems that exudation of macromolecules, transpiration and evaporation and high reactivity of NPs are three important factor which responsible for uptake of these particles in plant tissues. Probably, high iron accumulation on the root surface at high concentrations of NZVI (75:25 and 100:0) causes iron deficiency in the aerial part of broccoli plants.

2- At high levels of bicarbonate ( $\mathrm{pH}=8.5$ ), with the addition of $\mathrm{NI} / \mathrm{Iron}$ chelate up to $50 \mathrm{mg} \mathrm{L}^{-1}$, the SPAD, and Fv/Fm index, Photosynthetic pigments and root growth showed a significant increase compared to the control treatment, which can be considered as one of the ways to increase iron absorption under high bicarbonate conditions of water or soil.

3- The results of this experiment showed that nano scale zero valent iron powders in comparison with control, even with a lower concentration ( 25 and $50 \mathrm{mg} \mathrm{L}^{-1}$ ), could increase the growth of broccoli plants. Therefore it is also recommended that for further investigations, instead of concentration of $\mathrm{mg}$ $\mathrm{L}^{-1}$, the concentration of $\mu \mathrm{g} \mathrm{L^{-1 }}$ NZVI used for future research. Also, the effect of this type of nanoparticles on nutrition and human health requires further studies.

\section{References}

Anonymus, (2019).www. Statista.com

Appleton, E. A. (1996). Nickel-Iron wall against contaminated groundwater. Environmental science and technology, 30, 536-539.

Bonetti, E., Del Bianco, L., Pasquini, L., \& Sampaolesi, E. (1999). Thermal evolution of ball milled nanocrystalline iron. Nanostructured Materials, 12 (5-8), 685-688. 
Cao, J., Wei L., Huang, Q., Wang, L., \& Han, S. (1999). Reducing degradation of azo dye by zerovalent iron in aqueous solution. Chemosphere, 38 (3), 565-571.

Carter, C. T., Grieve, C. M., \& Poss J. A. (2005). Salinity effects on emergence, survival and ion accumulation of Limonium perezii. Journal of Plant Nutrition, 28, 1243-1257.

Carter, G. A., \& Knapp A. K. (2001). Leaf optical properties in highest plants: linking spectral characteristics to stress and chlorophyll concentration. American Journal of Botany, 88 (4), 677-684.

Dufkova, V. (1984). EDTA in algal culture media. Archiv for hydrobiologie. Supplement volumes. Algological Studies, 37, 479-492.

Ghafariyan, M. H., Malakouti, M. J., Dadpour, M. R., Stroeve, P., \& Mahmoudi, M. (2013). Effects of Magnetite Nanoparticles on Soybean Chlorophyll. Environmental science and technology, 47, 10645-10652.

Guo, F.A., Trannoy, N., \& Lu, J. (2004). Analysis of thermal properties by scanning thermal microscopy in nanocrystallized iron surface induced by ultrasonic shot peening. Materials Science and Engineering: A, 369 (1-2), 36-42.

He, J., Aminda Chua, N.Y., \& Qin, L. (2007). Interaction between iron stress and root-zone temperature on physiological aspects of aeroponically grown Chinese broccoli. Journal of Plant Nutrition, 31 (1), 173-192.

Hoornweg, D., \& Bhada-Tata, P. (2012). What a waste: a global review of solid waste management.

Jia, G., Wang, H., Yan, L., Wang, X., Pei, R., Yan, T., Zhao, Y., \& Guo, X. (2005). Cytotoxicity of carbon nanomaterials: Single-wall nanotube, multi-wall nanotube, and fullerene. Environmental science and technology, 39 (5), 1378-1383.

Judy, J. D., Unrine, J. M., Rao, W., Wirick, S., \& Bertsch, P. M. (2012). Bioavailability of gold nanomaterials to plants: importance of particle size and surface coating. Environmental science and technology, 46 (15), 8467-8474.

Li, F., Vipulanandan C., Kishore, K., \& Mohanty, K. K. (2003). Microemulsion and solution approaches to nanoparticle iron production for degradation of trichloroethylene. Colloids and Surfaces A: Physicochemical and Engineering Aspects, 223, 103-112.

Lichtenthaler, H. K., \& Buschmann, C. (2001). Current Protocols in Food Analytical Chemistry. Unit F4.3.1-F4.3.8.

Nowack, B., \& Bucheli, T. D. (2007). Occurrence, behavior, and effects of nanoparticles in the environment. Environment Pollution, 150 (1), 5-22.

Oviedo, C., \& Rodriguez, J. (2003). EDTA: The chelating agent under environmental scrutiny. Quimica Nova, 26 (6), 901-905.

Pena-Olmos, J. E., \& Casierra-Posada F. (2013). Photochemical efficiency of photosystem II (PSII) in broccoli plants (Brassica oleracea var Italica) affected by excess iron. Orinoquia, 17(1), 15-22.

Rauch, J., Kolch, W., Laurent, S., \& Mahmoudi, M. (2013). Big signals from small particles: Regulation of cell signaling pathways by nanoparticles. Chemical reviews, 113 (5), 3391-3406.

Remya, N., Saino, H. V., Baiju, G., Maekawa, T., Yoshida, Y., \& Sakthi Kumar, D. (2010). Nanoparticulate material delivery to plant. Plant Science, 179, 154-163.

Rico, C. M., Majumdar, S., Duarte-Gardea, M., Peralta-Videa, J. R., \& Gardea-Torresdey, J. L. (2011). Interaction of nanoparticles with edible plants and their possible implications in the food chain. Journal of Agricultural and Food Chemistry, 59 (8), 3485-3498.

Sheykhbaglou, R., Sedghi, M., Shishevan, M. T., \& Sharifi, R. S. (2010). Effects of nano-iron oxide particles on agronomic traits of soybean. Notulae Scientia Biologicae, 2 (2), 112-113.

Tan, X. M., \& Fugetsu, B. (2007). Multi-walled carbon nanotubes interact with cultured rice cells: Evidence of a self-defense response. Journal of Biomedical nanotechnology, 3, 285-288.

Vose, P. 1982. Iron nutrition in plants: A world overview. Journal of Plant Nutrition, 5 (4-7), 233-249.

Wang, C. B., \& Zhang, W. X. (1997). Synthesizing nanoscale iron particles for rapid and complete dechlorination of TCE and PCBs. Environmental science and technology, 31 (7), 2154-2156.

Wang, H., Kou, X., Pei, Z., Xiao, J. Q., Shan, X., \& Xing, B. (2011). Physiological effects of magnetite (Fe3O4) nanoparticles on perennial ryegrass (Lolium perenne L.) and pumpkin (Cucurbita mixta) plants. Nanotoxicology, 5 (1), 30-42. 
Yuan, G., Wang, X., Guo, R., \& Wang, Q. (2010). Effect of salt stress on phenolic compounds, glucosinolates, myrosinase and antioxidant activity in radish sprouts. Food Chemistry, 121 (4), 1014- 1019.

Zeng, Hui-Ping., Zhao, Y. Z., Lu, Y. F., Li, D., \& Zhang, J. (2017). Adsorption behaviors towards As and structural change of iron and manganese oxide sludge by thermal treatment. Environmental Science, 37 (8), 2986-2993.

Zhu, H., Han, J., Xiao, J. Q., \& Jin, Y. (2008). Uptake, translocation, and accumulation of manufactured iron oxide nanoparticles by pumpkin plants. Journal of Environmental Monitoring, 10 (6), 713-717.

Zhu, R. R., Wang, S. L., Chao, J., Shi, D. L., Zhang, R., Sun, X. \& Y., Yao, S. D. (2009). Bio-effects of nano-TiO2 on DNA and cellular ultrastructure with different polymorph and size. Materials Science and Engineering C, 29 (3), 691-696. 